\title{
Nutritional, mineral and organic acid composition of passion fruit (Passiflora species)
}

\author{
${ }^{1 *}$ Ramaiya, S.D., ${ }^{2}$ Bujang J.B., ${ }^{3}$ Zakaria, M.H. and ${ }^{1}$ Saupi, N. \\ ${ }^{I}$ Department of Crop Science, Faculty of Agriculture and Food Sciences, Universiti Putra Malaysia Bintulu \\ Sarawak Campus, 97008 Bintulu, Sarawak \\ ${ }^{2}$ Department of Biology, Faculty of Science, Universiti Putra Malaysia, 43400 UPM Serdang, Selangor \\ Darul Ehsan, Malaysia \\ ${ }^{3}$ Department of Aquaculture, Faculty of Agriculture, Universiti Putra Malaysia, 43400 UPM Serdang, \\ Selangor Darul Ehsan, Malaysia
}

\begin{abstract}
Article history:
Received: 30 September 2018 Received in revised form: 12 November 2018

Accepted: 28 November 2018

Available Online: 1

December 2018
\end{abstract}

\section{Keywords:}

Passiflora species,

Organic acid,

Proximate analysis,

Mineral content,

Mesocarp

\section{DOI:}

https://doi.org/10.26656/fr.2017.3(3).233

\begin{abstract}
This study focused on proximate composition, mineral content and organic acid properties of fruit juices from four Passiflora species; Passiflora edulis (Purple), Passiflora edulis (Frederick), Passiflora maliformis, and Passiflora quadrangularis and the mesocarp of Passiflora quadrangularis. The moisture content varied between $84.37 \pm 0.63 \%$ in $P$. edulis (Frederick) to $86.63 \pm 0.33 \%$ in mesocarp of $P$. quadrangularis. The ash content of mesocarp of $P$. quadrangularis was significantly lower $(0.51 \pm 0.02 \%)$ than its juice (1.37 $\pm 0.14 \%)$. Among the Passiflora species, P. edulis (Purple) and P. edulis (Frederick) possessed higher protein, $2.81 \pm 0.19 \%$ and $2.40 \pm 0.11 \%$, respectively. The fiber content in $P$. quadrangularis mesocarp was significantly higher $(8.49 \pm 0.40 \%)$ than other juices. Passiflora fruits have fat content $<0.5 \%$ in edible portion. The carbohydrate content of Passiflora fruit juices was not significantly different with ranged $6.57 \pm 0.29 \%$ in $P$. quadrangularis to $7.44 \pm 0.69 \%$ in P. edulis (Frederick). Additionally, a cup of $247 \mathrm{~mL}$ Passiflora juices provided $\sim 34 \%$ of potassium, $60-80 \%$ Magnesium, $>80 \%$ phosphorus and provides an adequate level of micronutrients especially Ferum content which is $90 \%$ of daily recommended allowance of minerals. The major organic acid in Passiflora fruit juice was citric acid and ranged $1137.00 \pm 0.13 \mathrm{mg} 100 \mathrm{~g}^{-1}$ in $P$. quadrangularis to

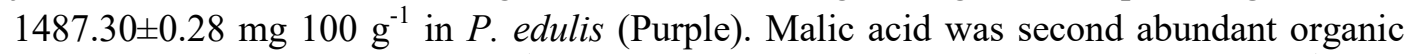

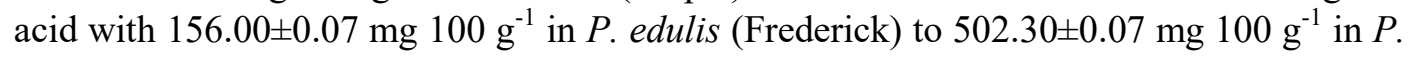
quadrangularis. Apart from the common species of Passiflora edulis, other lesser known Passiflora species are also gaining visibility in drinks, food and health promoter.
\end{abstract}

\section{Introduction}

Passiflora fruit also known as passion fruit is an exotic fruit that is popular for the startling beauty of its flower and fruity aroma. The main dispersal area extends over Central America and South America (Vanderplank, 2000; Krosnick and Freudenstein, 2005). Although 50 species bear edible fruits, only two forms of Passiflora edulis; i.e., Passiflora edulis (Purple passion fruit) and Passiflora edulis f. flavicarpa (Yellow passion fruit) are widely cultivated in commercial scale. The other species, e.g., Passiflora quadrangularis, Passiflora incarnata, Passiflora ligularis and Passiflora laurifolia are also cultivated in small scale for local consumption in certain countries.

In Peninsular Malaysia, the first record reported on the growing of Passiflora vines was in 1914 in small scale at Gunung Angsi, Negeri Sembilan. In the 1960s the Passiflora plants were grown in Ayer Hitam (Johor) and Cameron Highlands (Pahang) which were extended to be a commercial scale and the vines were successfully fruited (Chai, 1979). Thereafter, the P. edulis f. flavicarpa fruit production in these regions has been affected by a passion fruit woodiness diseases (PWD) which discouraged further expansion in commercial planting (Chai, 1979). However, in recent years this fruit is cultivated extensively due to prevalence of suitable growing conditions (Ramaiya et al., 2013) and also increasing demand for passion fruits in the local markets. This provide earning opportunities for local farmers and there is an immense potentiality of boosting passion fruit industry in Malaysia (Ramaiya et al., 2018). The region 
has good climate with sufficient rainfall and warm temperature with little variation in the photoperiod for growing a variety of horticultural crops very successfully.

It enters international trade mainly in the form of juice for fresh fruit (Bernacci et al., 2008). The juice is much concentrated and it is highly palatable beverage when diluted and sweetened. Passiflora juices are also used in other products, i.e., jelly, jam, sherbets, ice creams and yogurt. Passiflora edulis fruits also known as "Multivitamin juice" in Germany after apple juice (Fainsod, 2001). The Passiflora fruit being popular and accepted worldwide due to its fresh, unique aroma and flavor which are the results of natural combinations of volatile constituents in a well-balanced system including of minerals, sugar, organic acids and phenolic compounds.

The physical and chemical composition of Passiflora fruit can vary according to cultivars, environmental factors including climate and soil condition and agricultural practices (Macrae et al., 2007). The quantitative information about the fruit's content are the most important factors to verify the authenticity and quality index for fruits used in food manufacturing (Chavan and Kadam, 1995; Liu et al., 2006; Kelebek and Selli, 2011). Demands for Passiflora fruit juice are increasing not only because of the organoleptic properties but also due to its essential nutrients content. Passiflora fruit is a very good source of fiber, minerals especially potassium and it is low in sodium, yields zero cholesterol and possessed good amount of phenolic and ascorbic acid content (Sandi et al., 2004). The organic acid composition of fruits is also of interest because of its important influence on the sensory properties of fruit juices and considered very vital for food and beverage technology for quality evaluation (Hasib et al., 2002). Accurate knowledge of organic acid levels might be useful for determining the percentage juice and also for detecting misbranding or adulteration in fruit juices, since each fruit has a unique pattern of organic acids.

The physicochemical properties of Passiflora fruit has been investigated by researchers from various geographical locations on the most important commercial Passiflora fruits; P. edulis f. flavicarpa (Sandi et al., 2004; Sema and Maiti, 2011; Janzantti et al., 2012; Macoris et al., 2012) and P. edulis (Frank et al., 2006; Kishore et al., 2011). However scientific research has not kept up with this expansion and recently greater attention is being directed to other lesser known Passiflora species as well. Thus, this led to the interest in researching this plant species. Therefore, the aim of this study was to determine the proximate, minerals and organic acid compositions of fruit juices come from Passiflora fruit species cultivated in local tropical climate. Evaluating their nutritional status can help to understand the worth of this fruit to be processed as juice and other processed products.

\section{Materials and methods}

\subsection{Fruit harvest and storage}

Five to ten kilograms ( $\simeq 70-150$ fruits) vine-ripened fruits (based on fruit's skin colour and firmness) of $P$. edulis (Purple), P. edulis (Frederick), P. maliformis and about $50 \mathrm{~kg}$ (thirty fruits) $P$. quadrangularis were harvested randomly from twenty plants for each species at the Passiflora fruit farm, Universiti Putra Malaysia Bintulu Sarawak Campus, Sarawak during the fruitbearing seasons. The fruits were brought to the laboratory and immediately inspected and cleaned with distilled water. Fruits were dissected into half and the pulps were scooped with a spoon. The pulps were mechanically separated from the seeds. The pulps were oven dried at $60^{\circ} \mathrm{C}$ until constant weight was obtained and all the dried samples were homogenized to a fine powder and stored in airtight containers.

\subsection{Determination of proximate composition in Passiflora fruit juices}

Proximate analysis for the juice of Passiflora species; moisture content, ash, crude protein, crude lipid and crude fiber composition were determined using the standard methods of the Association of Official Analytical Chemists (AOAC, 2000) as described below. The moisture content of the juice sample was determined by drying the sample until constant weight was obtained based on Osborne and Voogt (1978). Ash value was determined by incinerating air-dried samples in a muffle furnace at $550^{\circ} \mathrm{C}$ for $5-6$ hours (method 930.05). The percentage of crude protein content was determined by multiplying the percentage of nitrogen content obtained from the samples using Kjeltec Auto Distillation 2200 Foss by a factor of 6.25 (method 955.04). The crude lipid was extracted using petroleum ether from the samples. Crude lipid was determined using 2055 Soxtec Avanti Manual System, Sweden (method 920.39). Crude fiber was estimated by acid-base digestion based on method 993.19. The seeds were also analyzed for total dietary fiber (method 985.29), insoluble fiber and soluble fiber (method 991.43) were according to an enzymaticgravimetric procedure. Available carbohydrate was estimated by difference, by subtracting the total sum of percent crude protein, crude lipid, crude fiber, ash and moisture from $100 \%$ dry weight (DW) basis of the seeds. 
2.3 Determination of mineral content in Passiflora fruit juice

The ash obtained from the determination of ash content was used to extract the minerals using the dryashing method as following the AOAC (2000). The mineral elements; calcium $(\mathrm{Ca})$, potassium $(\mathrm{K})$, sodium $(\mathrm{Na})$, magnesium $(\mathrm{Mg})$, iron $(\mathrm{Fe})$, zinc $(\mathrm{Zn})$, copper $(\mathrm{Cu})$ and manganese $(\mathrm{Mn})$ concentration were determined by atomic absorbance spectrophotometer (AA800 PerkinElmer, Germany based on method 975.03) with each determination was performed in triplicate. Phosphorus (P) was determined by colorimetric method using UVVIS spectrophotometer (Murphy and Ridley, 1962).

\subsection{Determination of organic acid in Passiflora fruit juice}

Five (5) $\mathrm{mL}$ of pulp was centrifuged twice at $2500 \mathrm{x}$ $g$ for 5 mins and at $20000 \times g$ for another 10 mins to separate the juice from pulp. The juices were then diluted at the proportion of 1:50 with mobile phase and kept refrigerated at $4^{\circ} \mathrm{C}$ until analysis. Prior to injection, all juices were filtered through $0.45 \mu \mathrm{m}$ pore size membrane filter and $10 \mu \mathrm{L}$ were used per injection. For organic acids analysis, a UV-Vis detector monitored at $210 \mathrm{~nm}$ and an Aminex HPX-87H column (300 x $7.8 \mathrm{~mm})$ (BioRad, U.S.A) was used. The column is a cation exchange column equipped with a cation $\mathrm{H}^{+}$. The juices were isocratically separated through the column at a flow rate of $0.8 \mathrm{~mL} \mathrm{~min}{ }^{-1}$. The temperature of the column was set at to $65^{\circ} \mathrm{C}$. Mobile phase was $0.013 \mathrm{~N} \mathrm{H}_{2} \mathrm{SO}_{4}$. Organic acids in juices were identified by comparing their retention times. The standard retention times for citric, malic, lactic and acetic acids were 7.3, 8.9, 12.0 and 14.4 min, respectively.

\subsection{Statistical analysis}

Mean, standard deviation and range were computed for triplicate determination. The data for proximate composition, mineral content and organic acids content were statistically analysed using SAS window programme 9.1 (SAS, Buckinghamshire, UK). Means were compared using single-factor ANOVA. Post-hoc Tukey's $(p<0.05)$ was performed if the ANOVA result was significant.

\section{Results and discussion}

\subsection{Proximate composition of Passiflora juices}

Fruits have been a part of the human diet over the years. They contain high quantity of water, carbohydrate, sugars, vitamins, minerals and organic compounds which are required by the body to function well (Onibon et al., 2007; Dimari and Hati, 2010). Nutritionist has advised that intake of least five portions of fruits and vegetable a day can help people to maintain good health, protecting them from heart disease, cancer, diabetes and kidney stones (Food Commission, 2009; USDA, 2011). For the fruit of Passiflora species is always used for its juicy pulp, while in $P$. quadrangularis, the fruit mesocarp is also eaten, which is unique. Its texture is like a guava, fleshy and a juicy like a melon and the taste is often mild sweetness.

The proximate compositions of the Passiflora fruit juices are presented in Table 1. The proximate content of Passiflora juices was categorically represented as moisture $>$ carbohydrate $>$ fiber $>$ protein $>$ ash $>$ fat and this trend was contradictory to the mesocarp of $P$. quadrangularis which is categorically represented as moisture $>$ carbohydrate $>$ fiber $>$ fat $>$ protein $>$ ash. The moisture content varied between $84.37 \pm 0.63 \%$ in $P$. edulis (Frederick) to $86.63 \pm 0.33 \%$ in mesocarp of $P$. quadrangularis with the remaining elements contributing to aroma, flavor and energy. The moisture content levels of the juices were comparatively higher which indicated them as a good source of medium for the functioning of enzymes and general metabolic processes. Moisture content is also important to both the stability and quality of juices. The ash content of mesocarp of $P$. quadrangularis was significantly lower $(0.51 \pm 0.02 \%)$ than its juice $(1.37 \pm 0.14 \%)$ and other Passiflora fruit juices studied. The ash content compared favourably with some fruits such as banana and guava but higher than the oranges $(0.44 \%)$, papaya $(0.39 \%)$ and pineapple $(0.22 \%)$. Juice samples with a high percentage of ash contents imply that the fruit contains high concentrations of various mineral contents, which are anticipated to speed up metabolic actions and improve growth and development (Martin, 1997; Bello et al., 2008). Generally, the Passiflora fruits possessed good protein and fiber compared to the other commercial fruits; i.e., pineapple, oranges, papaya and apple possessed lower values. The protein ranged from $1.13 \pm 0.11 \%$ to $2.81 \pm 0.19 \%$ for mesocarp of $P$. quadrangularis and $P$. edulis (Purple), respectively. A similar composition was observed for $P$. edulis (Purple) reported by USDA (2011) and NZ Passion Fruit Growers (2007), 2.20\% and $2.80 \%$, respectively. However, P. edulis f. flavicarpa possessed 2-3 times lower protein, 0.67\% (USDA, 2011)

Besides, the fiber content in $P$. quadrangularis mesocarp was significantly higher $(8.49 \pm 0.40 \%)$ than other investigated juices which ranged $2.40 \pm 0.11 \%$ to $4.31 \pm 0.31 \%$. Basically, the commercial fruits content lower fiber (less than $2.50 \%$ ). Adequate intake of dietary fiber can lower the risk of coronary heart disease, serum cholesterol level, constipation, hypertension, 


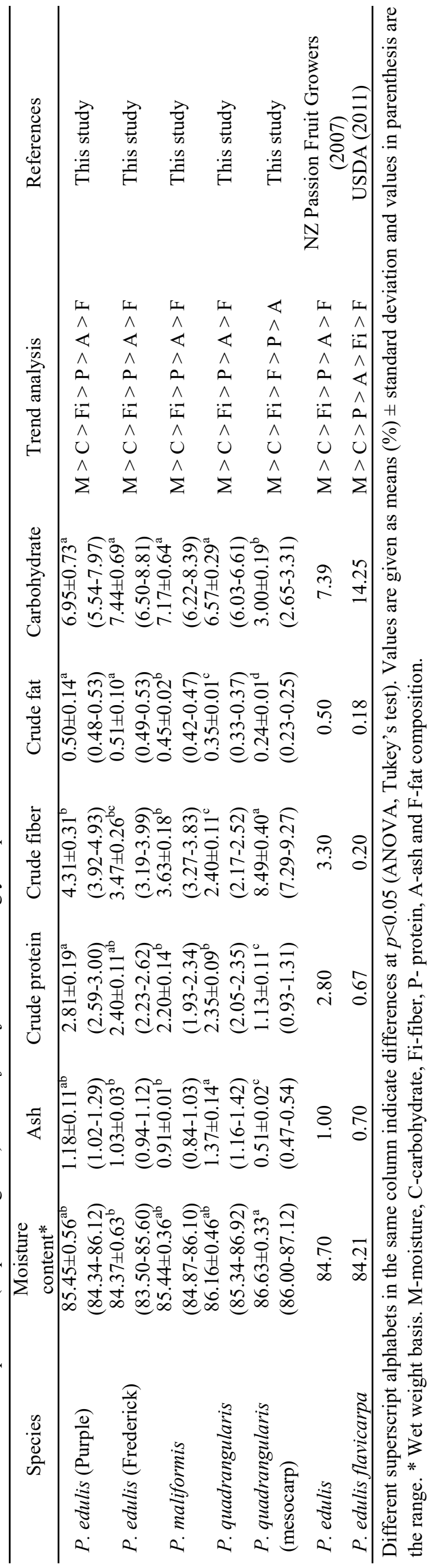

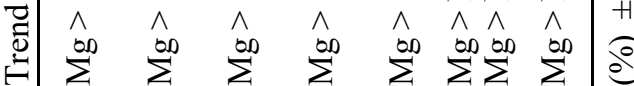

$\wedge \wedge \wedge \wedge \wedge \wedge \wedge \wedge$

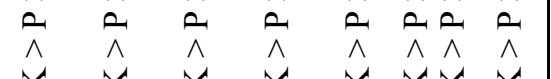

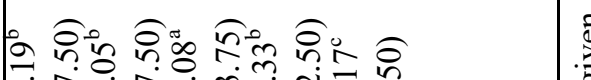

กิ

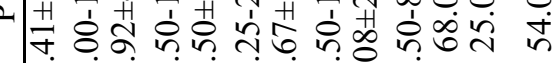

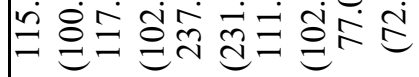

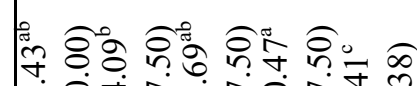

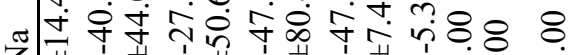

से 8 की

n.

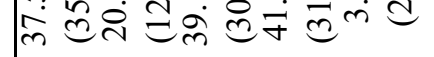

$\checkmark$ in कि

m

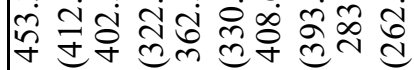

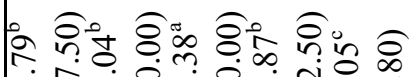

包

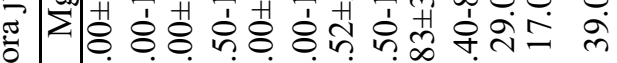

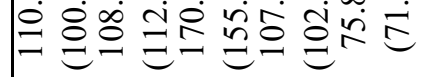

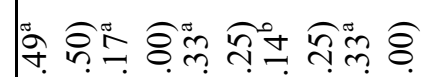

๙

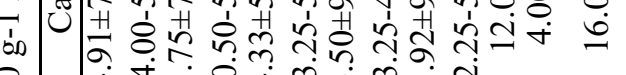

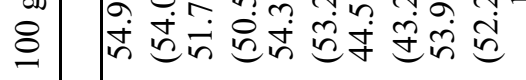

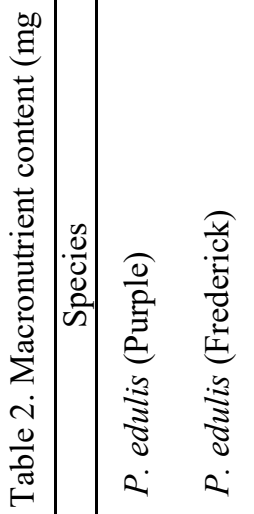

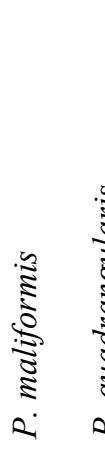

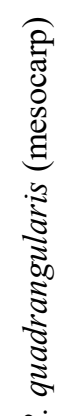

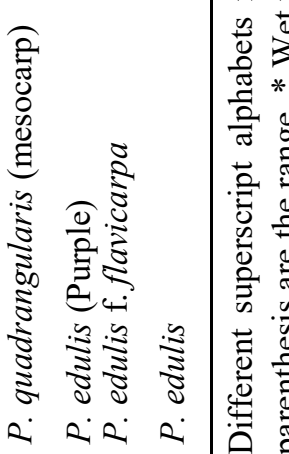


Table 3. Micronutrient content (mg $100 \mathrm{~g}^{-1} \mathrm{DW}$ ) of Passiflora juices accordingly to species

\begin{tabular}{|c|c|c|c|c|c|c|}
\hline Species & $\mathrm{Cu}$ & $\mathrm{Zn}$ & $\mathrm{Fe}$ & Mn & Trend & References \\
\hline P. edulis (Purple) & $\begin{array}{l}0.12 \pm 0.29^{\mathrm{ab}} \\
(0.11-0.34)\end{array}$ & $\begin{array}{l}0.30 \pm 2.08^{b} \\
(0.29-0.34)\end{array}$ & $\begin{array}{l}3.13 \pm 1.09^{\mathrm{a}} \\
(3.09-3.35)\end{array}$ & nd & $\mathrm{Fe}>\mathrm{Zn}>\mathrm{Cu}>\mathrm{Mn}$ & This study \\
\hline P. edulis (Frederick) & $\begin{array}{l}0.11 \pm 0.89^{a b} \\
(0.09-0.13)\end{array}$ & $\begin{array}{l}0.28 \pm 1.53^{6} \\
(0.25-0.30)\end{array}$ & $\begin{array}{l}2.98 \pm 0.93^{\mathrm{a}} \\
(2.84-3.10)\end{array}$ & nd & $\mathrm{Fe}>\mathrm{Zn}>\mathrm{Cu}>\mathrm{Mn}$ & This study \\
\hline P. maliformis & $\begin{array}{l}0.11 \pm 2.08^{a b} \\
(0.10-0.17)\end{array}$ & $\begin{array}{l}0.46 \pm 0.88^{a} \\
(0.45-0.48)\end{array}$ & $\begin{array}{l}1.22 \pm 0.33^{b} \\
(1.15-1.25)\end{array}$ & nd & $\mathrm{Fe}>\mathrm{Zn}>\mathrm{Cu}>\mathrm{Mn}$ & This study \\
\hline P. quadrangularis & $\begin{array}{l}0.16 \pm 1.50^{\mathrm{a}} \\
(0.15-0.19)\end{array}$ & $\begin{array}{l}0.42 \pm 1.09^{\mathrm{a}} \\
(0.40-0.44)\end{array}$ & $\begin{array}{l}3.37 \pm 1.36^{\mathrm{a}} \\
(3.10-3.55)\end{array}$ & nd & $\mathrm{Fe}>\mathrm{Zn}>\mathrm{Cu}>\mathrm{Mn}$ & This study \\
\hline $\begin{array}{l}\text { P. quadrangularis } \\
\text { (mesocarp) }\end{array}$ & $\begin{array}{l}0.07 \pm 0.87^{b} \\
(0.06-0.09)\end{array}$ & $\begin{array}{l}0.17 \pm 0.87^{\mathrm{c}} \\
(0.15-0.18)\end{array}$ & $\begin{array}{l}1.25 \pm 1.16^{b} \\
(1.05-1.45)\end{array}$ & nd & $\mathrm{Fe}>\mathrm{Zn}>\mathrm{Cu}>\mathrm{Mn}$ & This study \\
\hline P. edulis (Purple) & 0.09 & 0.10 & 1.60 & nd & $\mathrm{Fe}>\mathrm{Zn}>\mathrm{Cu}>\mathrm{Mn}$ & USDA (2011) \\
\hline P. edulis f. flavicarpa & 0.05 & 0.06 & 0.36 & nd & $\mathrm{Fe}>\mathrm{Zn}>\mathrm{Cu}>\mathrm{Mn}$ & USDA (2011) \\
\hline P. edulis & 0.12 & 0.80 & 1.10 & 0.09 & $\mathrm{Fe}>\mathrm{Zn}>\mathrm{Cu}>\mathrm{Mn}$ & $\begin{array}{c}\text { NZ Passion Fruit } \\
\text { Growers (2007) }\end{array}$ \\
\hline
\end{tabular}

Different superscript alphabets in the same column indicate differences at $p<0.05$ (ANOVA, Tukey's test). Values are given as means $(\mathrm{mg}) \pm$ standard deviation and values in parenthesis are the range. nd-not detected, na-not available.

diabetes, colon and breast cancer (Chau and Huang, 2004). Most fruits have fat content $<0.5 \%$ in edible portion. This is in line with fat content observed in Passiflora fruit juices with ranged $0.24 \pm 0.01 \%$ to $0.51 \pm 0.10 \%$. The amount of fats will make certain vitamins available for use in the body and makeup part of all body cells and help to maintain body temperature. The carbohydrate content of Passiflora fruit juices was not significantly different with ranged $6.57 \pm 0.29 \%$ in $P$. quadrangularis to $7.44 \pm 0.69 \%$ in $P$. edulis (Frederick). The mesocarp of $P$. quadrangularis possessed significantly two times lower carbohydrate content $3.00 \pm 0.19 \%$ compared to its juice $(6.57 \pm 0.29 \%)$. The carbohydrate values obtained were within the range of previously reported content in P. edulis was $7.39 \%$. Passiflora fruit juices with low carbohydrate might be ideal for diabetic and hypertensive patients requiring low sugar diets.

\subsection{Mineral content of Passiflora juices}

Minerals are of prime importance in determining the fruit nutritional value. The ash content of the Passiflora fruit juices was relatively high $(0.51-1.37 \%)$ as compared to other commercial fruits; e.g., oranges, banana and papaya which further confirm its high mineral content. This is agreeable with a previous study of Rao (1996), where a high amount of ash content in plants is an indication that the plant provides considerable amount of minerals that essential for the body. The macronutrient and micronutrient content of Passiflora juice are presented in Table 2 and Table 3, respectively. The Passiflora fruit juices were found to contain appreciable quantity of $\mathrm{K}, \mathrm{Ca}, \mathrm{Mg}, \mathrm{Na}, \mathrm{P}$ and $\mathrm{Fe}$. The trend of macronutrients content in all the Passiflora fruit juices studied was categorical as, i.e., $\mathrm{K}>\mathrm{P}>\mathrm{Mg}>$ $\mathrm{Ca}>\mathrm{Na}$. The trend of macronutrient content can be varied even in similar species, e.g., $P$. edulis reported by possessed lower $\mathrm{Ca}$ content than $\mathrm{Na}$. This may be attributed to environmental conditions which have effects on the plant nutrition attributes (Martin, 1997; Babasaheb, 2000; Wardlaw, 2003).

The nutrients were found to be available in good quality and quantity and they were found to meet the daily requirement in children, adult, pregnant and lactating mothers. As in many other fruits, $\mathrm{K}$ is the most abundant mineral in the Passiflora fruit. The levels of $\mathrm{K}$ range from $283.33 \pm 8.33 \mathrm{mg} 100 \mathrm{~g}^{-1}$ for $P$. quadrangularis mesocarp to $453.33 \pm 32.87 \mathrm{mg} 100 \mathrm{~g}^{-1}$ in P. edulis (Purple). Potassium concentration in P. edulis (Purple) was slightly higher than the reported value (348 mg $100 \mathrm{~g}^{-1}$ ) by USDA (2011). The $\mathrm{K}$ content of Passiflora fruit juices was similar to guava $(417 \mathrm{mg} 100$ $\mathrm{g}^{-1}$ ) and significantly higher than other fruits that possessed the least $\mathrm{K}$ content; orange (181 mg $\left.100 \mathrm{~g}^{-1}\right)$ and pineapple (109 mg $100 \mathrm{~g}^{-1}$ ) as reported by USDA (2011). Passiflora fruit provides a significant source of the $\mathrm{K}$, an important in blood pressure control and acidbase balance (Martin, 1997; Wardlaw, 2003).

Passiflora fruit excels as an alternative to other fruits such as oranges and banana. The recommended dietary allowance (RDA) for men and women (19-30 years old) are presented in Table 4 and Table 5. A cup or an equivalent of $247 \mathrm{~g}$ of Passiflora fruit juice provides $1119.73 \mathrm{mg}$ of potassium or about $23 \%$ out of the daily estimated recommendation of $4700 \mathrm{mg}$. The least P level was recorded in mesocarp of $P$. quadrangularis, $77.08 \pm 29.17 \mathrm{mg} 100 \mathrm{~g}^{-1}$ and highest in P. maliformis (237.50 $\left.\pm 36.08 \mathrm{mg} 100 \mathrm{~g}^{-1}\right)$. The obtained value for $P$. edulis (Purple) was approximately two times higher $\left(115.41 \pm 53.19 \mathrm{mg} 100 \mathrm{~g}^{-1}\right)$ than the reported values, 68 $\mathrm{mg} 100 \mathrm{~g}^{-1}$ (USDA, 2011) and $54 \mathrm{mg} 100 \mathrm{~g}^{-1}$ (NZ, 2007). Phosphorus is important to the fundamental process of metabolism in the body and gives strength and rigidity to bones and teeth (Martin, 1997; Babasaheb, 2000; Wardlaw, 2003). 

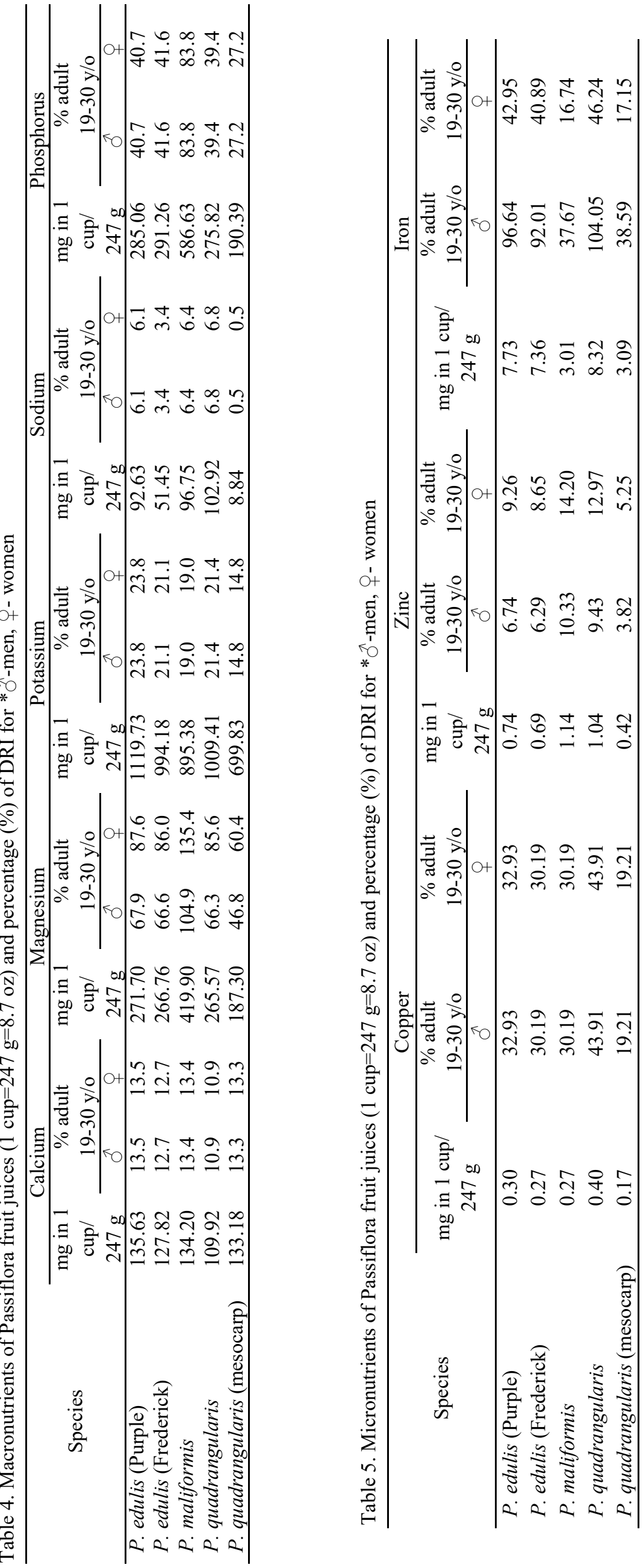
The $\mathrm{Mg}$ content in Passiflora fruit juices ranged

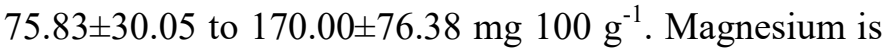
an essential component of a healthy human diet. It is a co -factor in a number of enzyme systems and along with $\mathrm{Ca}$ it is involved in neuro-chemical transmission and muscular excitability (Martin, 1997; Wardlaw, 2003). The daily value for $\mathrm{Mg}$ is $400 \mathrm{mg}$ for male and $310 \mathrm{mg}$ for female at age of 19-30 years old. Calcium is essential in bone formation and strength. The $\mathrm{Ca}$ content in

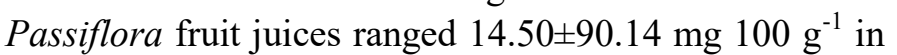
$P$. quadrangularis to $24.91 \pm 79.49 \mathrm{mg} 100 \mathrm{~g}^{-1}$ in $P$. edulis (Purple). Intake of the Passiflora fruits would be helpful for the normal functioning of the blood coagulation. The Na content in Passiflora fruits juices was ranged $20.83 \pm 44.09$ to $41.67 \pm 80.47 \mathrm{mg}_{100 \mathrm{~g}^{-1} \text { and }}$ the least content was observed in $P$. quadrangularis mesocarp (3.58 $\left.\pm 7.41 \mathrm{mg} 100 \mathrm{~g}^{-1}\right)$. The $\mathrm{Na}$ content in Passiflora fruits was higher than other fruits; i.e., papaya $\left(8.00 \mathrm{mg} 100 \mathrm{~g}^{-1}\right)$ and guava $\left(2.00 \mathrm{mg} 100 \mathrm{~g}^{-1}\right.$ some fruits like oranges and apple does not contain $\mathrm{Na}$. The present $\mathrm{Na}$ content was slight higher than previously reported works for $P$. edulis (Purple) and P. quadrangularis; $28.00 \mathrm{mg} 100 \mathrm{~g}^{-1}$ (USDA, 2011). A cup of Passiflora fruit juice supplies $3-6 \%$ of the daily requirement for $\mathrm{Na}$ (Table 4).

Nutritionally, one serving of $274 \mathrm{~g}$ of Passiflora fruit juice provides an adequate level of micronutrients especially $\mathrm{Fe}$ content. The trend for micronutrient in Passiflora fruit juices was $\mathrm{Fe}>\mathrm{Zn}>\mathrm{Cu}$. Manganese (Mn) was not detectable in investigated Passiflora fruit juices. However, a trace amount of this element was detected in P. edulis (Purple) with $0.09 \mathrm{mg} 100 \mathrm{~g}^{-1}$ (USDA, 2011) and other commercial fruits; i.e., oranges (0.03 mg $\left.100 \mathrm{~g}^{-1}\right)$, banana $\left(0.27 \mathrm{mg} 100 \mathrm{~g}^{-1}\right)$ and pineapple $\left(0.93 \mathrm{mg} 100 \mathrm{~g}^{-1}\right)$. The micronutrient trend in Passiflora fruit juices was similar to reported Passiflora fruits (USDA, 2011) and commercial fruits i.e., oranges and papaya (USDA, 2011). Among the studied species, $P$. edulis (Purple), $P$. edulis (Frederick) and $P$. quadrangularis significantly high in $\mathrm{Fe}$ content; $3.13 \pm 1.09 \mathrm{mg} 100 \mathrm{~g}^{-1}, 2.98 \pm 0.93 \mathrm{mg} 100 \mathrm{~g}^{-1}$ and $3.37 \pm 1.36 \mathrm{mg} 100 \mathrm{~g}^{-1}$, respectively and the least content were recorded in $P$. maliformis and mesocarp of $P$. quadrangularis; $1.22 \pm 0.33 \mathrm{mg} 100 \mathrm{~g}^{-1}$ and $1.25 \pm 1.16 \mathrm{mg}$ $100 \mathrm{~g}^{-1}$, accordingly. Passiflora fruit is a rich source of non-heme or plant-based, iron. Iron is very important in the formation of red blood cells. It is a vital element in the diet of pregnant women and infants (Martin, 1997; Babasaheb, 2000; Oluyemi et al., 2006). The recommended dietary allowance of iron for men (19-30 years old) is $8 \mathrm{mg}, 18 \mathrm{mg}$ for women and during pregnancy is $27 \mathrm{mg}$ (Bello et al., 2008; Dimari and Hati, 2010).
A cup of $P$. edulis and $P$. quadrangularis juices can provide $>90 \%$ for men and $>40 \%$ for women of the recommended allowance for $\mathrm{Fe}$ (Table 5). The concentrations of $\mathrm{Zn}$ and $\mathrm{Cu}$ in Passiflora juices was found to be within the limits of recommended maximum level allowed in food based on Malaysian Food Regulations (1985) limit with (3.00 and $4.00 \mathrm{mg} 100 \mathrm{~g}^{-1}$, respectively). Similar with other fruits $\mathrm{Cu}$ content in Passiflora juices ranged $0.07 \pm 0.87 \mathrm{mg} 100 \mathrm{~g}^{-1}$ to $0.16 \pm 1.50 \mathrm{mg} 100 \mathrm{~g}^{-1}$. The mesocarp of $P$. quadrangularis possessed the lowest concentration of $\mathrm{Zn}$ $\left(0.17 \pm 0.87 \mathrm{mg} 100 \mathrm{~g}^{-1}\right)$ while $P$. maliformis $(0.46 \pm 0.88$ $\left.\mathrm{mg} 100 \mathrm{~g}^{-1}\right)$ had the highest. Passiflora fruit juices also contain approximately $10 \%$ of the daily requirements for $\mathrm{Zn}$ and $30 \%$ of $\mathrm{Cu}$. Based on the results above, the Passiflora species growing in UPMKB, although grown under the same soil and environment conditions, yet possessed different nutrient content and this may be attributed to cultivars or species itself. The nutrient content varied even among similar species which grown under different geographical location and it could be due to the effects of different environment (Wardlaw, 2003).

\subsection{Organic acids content of Passiflora juices}

Organic acids play important roles in Passiflora fruit juices because of their influence on the organoleptic properties (flavor, color and aroma) as well as the stability and microbiological control of the products (Hasib et al., 2002). Three organic acids were identified and quantified in Passiflora fruit juice was citric, malic and acetic acids (Table 6). There was significant difference between organic acids level and Passiflora fruit species. The major organic acid in Passiflora fruit juice was citric acid and ranged $1137.00 \pm 0.13 \mathrm{mg}^{100 \mathrm{~g}^{-}}$

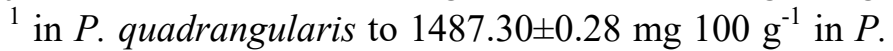
edulis (Purple). One distinctive quality of the Passiflora species is the high citric acid content (Fainsod, 2001). Like lemon and lime juice, Passiflora fruit juice is quite acidic.

Malic acid was second abundant organic acid in the Passiflora fruit juices with $156.00 \pm 0.07 \mathrm{mg} 100 \mathrm{~g} \mathrm{~g}^{-1}$ in $P$. edulis (Frederick) to $502.30 \pm 0.07 \mathrm{mg} 100 \mathrm{~g}^{-1}$ in $P$. quadrangularis. In $P$. edulis f. flavicarpa, citric acid constitute about $83.00 \%$ of the acids, followed by malic, which constituted about $15.90 \%$ of the acid content (Joy, 2010). Although Purple Passiflora fruit (P. edulis) was found to contain the same acids as Yellow Passiflora fruit ( $P$. edulis f. flavicarpa), the relative abundance of each of the acids differed markedly as shown in the present study compared to previous works. Mesocarp of P. quadrangularis possessed the least organic acids compared to its juices. The content of citric acid in mesocarp is 15 times lower $\left(72.00 \pm 0.03 \mathrm{mg} 100 \mathrm{~g}^{-1}\right)$ than its juice.

C 2018 The Authors. Published by Rynnye Lyan Resources 
Table 6. Organic acids content (mg $\left.100 \mathrm{~g}^{-1} \mathrm{FW}\right)$ of Passiflora juices accordingly to species

\begin{tabular}{|c|c|c|c|c|c|}
\hline Species & Citric acid & Acetic acid & Malic acid & Lactic acid & References \\
\hline P. edulis (Purple) & $\begin{array}{c}1487.30 \pm 0.28^{\mathrm{a}} \\
(1440.00-1538.00)\end{array}$ & $\begin{array}{c}11.00 \pm 0.01^{\mathrm{a}} \\
(10.00-12.00)\end{array}$ & $\begin{array}{c}257.70 \pm 0.14^{\mathrm{bc}} \\
(234.00-283.00)\end{array}$ & nd & This study \\
\hline P. edulis (Frederick) & $\begin{array}{c}1290.30 \pm 0.15^{\mathrm{b}} \\
(1263.00-1314.00)\end{array}$ & $\begin{array}{c}9.00 \pm 0.01^{\mathrm{a}} \\
(8.00-10.00)\end{array}$ & $\begin{array}{c}156.00 \pm 0.07^{\mathrm{c}} \\
(146.00-169.00)\end{array}$ & nd & This study \\
\hline P. maliformis & $\begin{array}{c}1554.00 \pm 0.36^{\mathrm{a}} \\
(1483.00-1597.00)\end{array}$ & $\begin{array}{c}11.70 \pm 0.01^{\mathrm{a}} \\
(10.00-14.00)\end{array}$ & $\begin{array}{c}174.70 \pm 0.04^{\mathrm{c}} \\
(169.00-183.00)\end{array}$ & nd & This study \\
\hline P. quadrangularis & $\begin{array}{c}11370.00 \pm 0.13^{\mathrm{c}} \\
(1108.00-1154.00)\end{array}$ & $\begin{array}{c}12.30 \pm 0.01^{\mathrm{a}} \\
(10.00-14.00)\end{array}$ & $\begin{array}{c}502.30 \pm 0.07^{\mathrm{a}} \\
(489.00-510.00)\end{array}$ & nd & This study \\
\hline $\begin{array}{l}\text { P. quadrangularis } \\
\text { (mesocarp) }\end{array}$ & $\begin{array}{c}72.00 \pm 0.03^{\mathrm{d}} \\
(68.00-78.00)\end{array}$ & $\begin{array}{c}2.30 \pm 0.001^{\mathrm{b}} \\
(1.00-3.00)\end{array}$ & $\begin{array}{c}22.30 \pm 0.02^{\mathrm{d}} \\
(18.00-26.00)\end{array}$ & nd & This study \\
\hline P. edulis & 34.00 & na & 9.95 & 18.78 & Joy (2010) \\
\hline P. edulis & 340 & na & 130 & na & USDA (2011) \\
\hline P. edulis f. flavicarpa & 142.79 & na & 272.20 & 1.45 & Joy $(2010)$ \\
\hline
\end{tabular}

Different superscript alphabets in the same column indicate differences at $p<0.05$ (ANOVA, Tukey's test). Values are given as means $(\mathrm{mg}) \pm$ standard deviation and values in parenthesis are the range. nd-not detected, na-not available.

A lower concentration of acetic acid $(9.00 \pm 0.01$ $12.30 \pm 0.01 \mathrm{mg} 100 \mathrm{~g}^{-1}$ ) was also detected in Passiflora fruit juices. Lactic acid was not detected in examined samples. However, Joy (2010), reported the presence of lactic acid in $P$. edulis (Purple) and $P$. edulis f.

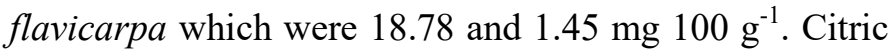
acid is a naturally occurring weak organic acid and very soluble and used as an additive to many drinks to enhance flavor and increase stability in soft drinks and syrups. It is also used to prevent color change by oxidation (Fainsod, 2001).

Citric and malic acid content in the Passiflora fruit could be responsible for the usual sourness of the fruits. It is an important component of cell metabolism in fruits and is the primary acid found in some fruits which plays a major role in metabolism in the human body. Citric and malic acid is also an indicator of the freshness of fruits and is used as a common parameter to evaluate the quality of agricultural products and food control points in the food process (Hasib et al., 2002).

\section{Conclusion}

The present findings showed the Passiflora fruit juices are a natural nutritious drink with contain all the necessary essential nutrients required by the body in the right proportion that meets the daily body requirements. The juices extracted from pulps of $P$. edulis, $P$. maliformis and $P$. quadrangularis possessed a rich source of fiber, protein and carbohydrate content. A cup of $247 \mathrm{~mL}$ Passiflora fruit juices provided $24 \%$ of $\mathrm{K}$, $60-80 \% \mathrm{Mg},>80 \% \mathrm{P}$ and $90 \% \mathrm{Fe}$ of recommended dietary allowance of minerals. Besides the juice, edible mesocarp of $P$. quadrangularis also contained ample of nutrient and favorable for human consumption. In addition, citric acid was the most dominant organic acid in Passiflora fruit juices followed by malic acid. A similar trend was recorded for mesocarp of $P$. quadrangularis with lower concentration compared to its juice. The quantitative information that gathered in this study, help to understand the worth of these fruits to be processed as juice and other processed products.

\section{Conflict of Interest}

The authors declare that they have no conflict of interest.

\section{Acknowledgments}

This study was funded by the Ministry of Higher Education Malaysia and UPM under the RUGS-01-01-12 -1592RU entitle 'Comparative studies on passion fruit species and their potential uses'.

\section{References}

AOAC. (2000). Official Method of Analysis of the Association of the Analytical Chemists. Maryland, USA: Association of Official Analytical Chemists

Babasaheb, B.D. (2000). Handbook of Nutrition and Diet. New York: Marcel Dekker, Inc.

Bello, M.O., Falade, O.S., Adewusi, S.R. and Olawole, N.O. (2008). Studies on the chemical compositions and anti-nutrients of some lesser known Nigeria fruits. African Journal of Biotechnology, 7(21), 3972 -3979 .

Bernacci, L.C., Soares-Scott, M.D., Junqueira, N.T.V., Passos, I.R.D.S. and Meletti, L. M.M. (2008). Passiflora edulis Sims: the correct taxonomic way to cite the yellow passion fruit (and of others colors). Revista Brasileira de Fruticulture, 30(2), 566-576. https://doi.org/10.1590/S010029452008000200053

Chai, T.B. (1979). Passion Fruit Culture in Malaysia: Fruit Research Branch. Malaysia: Malaysian 
Agricultural Research and Development Institute (MARDI).

Chau, C.F. and Huang, Y.L. (2004). Characterization of passion fruit seed fibers- a potential fiber source. Food Chemistry, 85(2), 189-194. https:// doi.org/10.1016/j.foodchem.2003.05.009

Chavan, U.D. and Kadam, S.S. (1995). Passion fruit. In D.K. Salunkhe and S.S. Kadam. Handbook of Fruit Science and Technology, Production, Composition, Storage and Processing, p. 445-454. New York: Marcel Dekker Inc.

Dimari, G.A. and Hati, S.S. (2010). Vitamin C composition and mineral content of some Nigerian packaged juices drinks. Journal of Life and Physical Sciences, 3, 129-134.

Fainsod, G.S. (2001). Composition and potential health benefits of passion fruit juice. Washington: American Chemical Society.

Food Commission, (2009). Food label fib. The Food Commission Research charity 94 White Lion Street, London, United Kingdom. Retrieved on September 16, 2015 from Website: http:// www.foodcomm.org.uk.

Frank, B.M., Harvey, E.A., James, O.G. and Silva, J.L. (2006). Studies on Postharvest Quality of Passion Fruit. Starkville: Mississippi State University.

Hasib, A., Jaouad, A., Mahrouz, M. and Khouili, M. (2002). HPLC determination of organic acids in Moroccan apricot. Ciencia Technology Aliment, 3 (4), 207-211. https:// doi.org/10.1080/11358120209487729

Janzantti, N.S., Macoris, M.S., Garruti, D.S. and Monteiro, M. (2012). Influence of the cultivation system in the aroma of the volatile compounds and total antioxidant activity of passion fruit. $L W T$ Food Science and Technology, 46(2), 511-518. https://doi.org/10.1016/j.lwt.2011.11.016

Joy, P.P. (2010). Status and Prospects of Passion Fruit Cultivation in Kerala: Pineapple Research Station. India: Kerala Agricultural University.

Kelebek, H. and Selli, S. (2011). Determination of volatile, phenolic, organic acid and sugar components in a Turkish cv. Dortyol (Citrus sinensis L.) orange juice. Journal of the Science of Food and Agriculture, 91, 1855-1862. https://doi.org/10.1002/ jsfa.4396

Kishore, K., Pathak, K.A., Shukla, R. and Bharali, B. (2011). Effect of storage temperature on physicochemical and sensory attributes of purple passion fruit (Passiflora edulis Sims). Journal of Food Science and Technology,48(4), 484-488. https:// doi.org/10.1007/s13197-010-0189-8
Krosnick, S.E. and Freudenstein, J.V. (2005). Monophyly and floral character homology of old world Passiflora. Systematic Botany, 30, 139-152. https://doi.org/10.1600/0363644053661959

Liu, H.-F., Wu, B.-H., Fan, P.-G., Li, S.-H. and Li, S.L. (2006). Sugar and acid concentrations in grape cultivars analyzed by principal component analysis. Journal of the Science of Food and Agriculture, 86 (10), 1526-1536. https://doi.org/10.1002/jsfa.2541

Macoris, M.S., de Marchi, R., Janzantti, N.S. and Monteiro, M. (2012). The influence of ripening stage and cultivation system on the total antioxidant activity and total phenolic compounds of yellow passion fruit pulp. Journal of the Science of Food and Agriculture, 92(9), 1886-1891. https:// doi.org/10.1002/jsfa.5556

Macrae, R., Robinson, R.K. and Sadler, M.J. (2007). Encyclopedia of Food Science, Food Technology and Nutrition. US: Academic Press Inc.

Malaysian Food Regulations (1985). Malaysian Law on Food and Drugs. Kuala Lumpur: Malaysia Law Publisher.

Martin, E. (1997). Principles of Human Nutrition. London: Chapman and Hall.

Murphy, J. and Riley, J.P. (1962). A modified single solution method for the determination of phosphate in natural waters. Analytica Chimica Acta, 27, 3136. https://doi.org/10.1016/S0003-2670(00)88444-5

NZ Passion fruit growers, (2007). New Zealand Passionfruit-nutritional information. Retrieved from Passion Fruit website: www.passionfruit.org.nz/.

Oluyemi, E.A., Akinlua, A.A., Adenuga, A.A. and Adebayo, M.B. (2006). Mineral contents of some commonly consumed Nigerian foods. European Journal of Scientific Research, 6(2), 11-15.

Onibon, V.O., Abulude, F.O. and Lawal, L.O. (2007). Nutritional and anti-nutritional composition of some Nigerian fruits. Journal of Food Technology, 5(2), 120-122.

Osborne, D.R. and Voogt, P. (1978). The Analysis of Nutrients in Foods. London: Academic press.

Ramaiya, S.D., Bujang, J.S., Zakaria, M.H., King, W.S. and Sahrir, M.A.S. (2013). Sugars, ascorbic acid, total phenolic content and total antioxidant activity in passion fruit (Passiflora) cultivars. Journal of the Science of Food and Agriculture, 93(5), 1198-1205. https://doi.org/10.1002/jsfa.5876

Ramaiya, S.D., Bujang, J.S. and Zakaria, M.H. (2018). Nutritive values of passion fruit (Passiflora species) seeds and its role in human health. Journal of Agriculture Food and Development, 4, 23-30.

Rao, P.U. (1996). Nutrient composition and biological 
evaluation of mesta (Hibiscus sabdariffa) seeds.

Plant Foods for Human Nutrition, 49(1), 27-34.

https://doi.org/10.1007/BF01092519

Sandi, D., Chaves, J.B.P., Sousa, A.C.G., Parreiras, J.F.M., Silva, M.T.C. and Constant, P.B.L. (2004). Hunter colour dimension, sugar content and volatile compounds in pasteurized yellow passion fruit juice (P. edulis var flavicarpa) during storage. Brazilian Archives of Biology and Technology, 47, 233-254. https://doi.org/10.1590/S1516-89132004000200011

Sema, A. and Maiti, C.S. (2011). Status and Prospects of Passion Fruit Industry in Northeast India. Retrieved on September 02, 2015 from Website: http:// ebookbrowse.com/status-of-passion-fruit industry.

USDA. (2011). Department of Agriculture (USDA) of the United State, National Nutrient Database for Standard Reference. Retrieved on September 20, 2015 from Website: http://ndb.nal.usda.gov/.

Vanderplank, J. (2000). Passion Flowers. Cambridge: MIT Press.

Wardlaw, G.M. (2003). Contemporary Nutrition. New York: Mc Graw Hill. 